\title{
Pott's puffy tumor of the vertex years after trauma in a diabetic patient: case report
}

\author{
Ç. Evliyaoğlu; G. Bademci; E. Yucel and S. Keskil
}

Department of Neurosurgery. Kirikkale University School of Medicine. Kirikkale. Turkey.

\section{Summary}

Pott's puffy tumor is a rare clinical entity characterized by subperiosteal abscess associated with osteomyelitis. It is usually seen as a complication of frontal sinusitis or trauma. This is the unique report of a Pott's puffy tumor located over the vertex of a type 1 diabetic patient with an unusual latency of 14 years following injury.

A 27-year old man presented with pain and a soft swelling on his vertex. Magnetic resonance imaging demonstrated subperiosteal abscess in the vertex region associated with dural thickening and perisinusal irregularities of epidural space. Further history revealed that he had a trauma to the same location when he was $\mathbf{1 3}$ years old.

Considering possible complications due to proximity of the lesion to the sagittal sinus, we retrained from aggressive surgical interventions. We treated our patient with a simple surgical abscess drainage followed by prolonged use of antibiotics and achieved complete therapy.

The cellular and humoral elements of the immune system may be disrupted in diabetic patients resulting in such atypical courses and complications of infections. We want to emphasize both importance of the prompt diagnosis of Pott's puffy tumor as intracranial invasion may cause severe neurologic problems, and importance of a surgical intervention tailored for the individual lesion.

KEY WORDS: Pott's puffy tumor. Osteomyelitis. Scalp abscess. Trauma. Diabetes

\section{Resumen}

El tumor "hinchado" de Pott es una entidad rara, caracterizada por un absceso subperióstico asociado a una osteomielitis. Se ve habitualmente como una com-

Recibido: 20-02-04. Aceptado: 26-03-04 plicación de sinusitis frontal o de un traumatismo. Esta es la única comunicación de un tumor hinchado de Pott localizado en el vértex craneal de un paciente diabético con una latencia, poco habitual, de 14 años.

Se presenta el caso de un varón de 27 años con dolor e hinchazón en el vértex. La resonancia magnética demostró un absceso subperióstico en la región del vértex, asociado a un engrosamiento de la duramadre e irregularidades en torno al seno longitudinal superior, en el espacio epidural. En la historia posterior se recogió que había sufrido un traumatismo en la misma localización cuando tenía 13 años.

Al considerar las posibles complicaciones, debido a la proximidad de la lesión al seno sagital, nos abstuvimos de un tratamiento quirúrgico muy agresivo. Tratamos al paciente con un drenaje simple del absceso, seguido de un tratamiento prolongado con antibióticos y se consiguió la curación completa.

Los elementos celulares y humorales del sistema inmunológico pueden estar alterados en los pacientes diabéticos, lo cual da lugar a evoluciones atípicas y a complicaciones infecciosas. Queremos poner de relieve la importancia de un diagnóstico precoz de un absceso de Pott, puesto que la invasión intracraneal puede dar lugar a graves problemas neurológicos, y la importancia de una intervención quirúrgica adecuada a cada tipo de lesión.

PALABRAS CLAVE: Tumor hinchado de Pott. Osteomielitis. Absceso del cuero cabelludo. Trauma. Diabetes.

\section{Introduction}

Pott's puffy tumor (PPT) was first described by Percivall Pott, in $1760^{5}$. It is generally described as a puffy swelling of the scalp resulting from a subperiosteal abscess associated with osteomyelitis of the bone ${ }^{9}$. The lesion almost always arises from an antecedent event or illness, the most common causes are trauma and frontal sinusitis. This paper describes a unique subperiosteal abscess located 


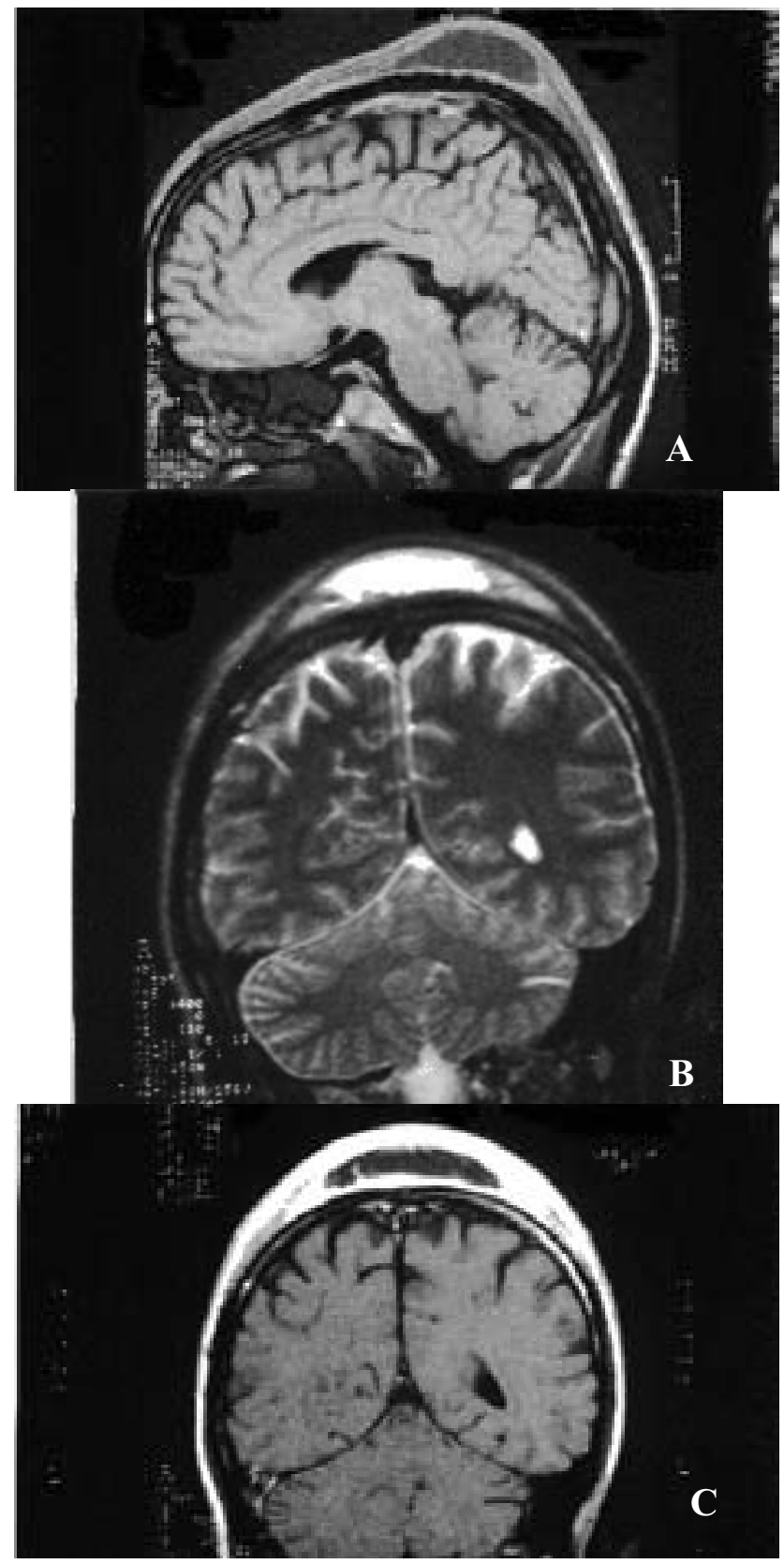

Figure 1: Sagittal T1-weighted (A), coronal T2-weighted (B) and coronal contrast-enhanced T1-weighted (C), magnetic resonance images of the patient demonstrating a subcutaneous soft tissue swelling and subperiosteal abscess in vertex region with dural thickening and perisinusal irregularities of epidural space.

over the vertex of a type 1 diabetic patient, resulting from a trauma that had occurred 14 years ago.

\section{Case report}

A 27 year old man was referred to our department with pain and a soft swelling on his vertex. It was learned that, he had hit the top of his head severely to a door lintel when he was 13 years old. A scalp laceration had been sutured without any problem. A diagnosis of type 1 diabetes mellitus was made when he was 17 years old and he has been under insulin therapy since that age. He was asymptomatic until three weeks before when he noticed an increasing swelling on his vertex associated with local tenderness, headache and fever. He stated that he drained a yellowish purulent material by himself and the reduced swelling recurred in ten days.

On admission, a tender and fluctuantly soft swelling $10 \mathrm{~cm}$ in diameter was present on the vertex crossing midline. Mobile lymph nodes enlarged to about two $\mathrm{cm}$ were located one at the right jugular region and two at the left occipital region. The neurological examination was normal. Laboratory investigations revealed the following as the positive findings: White blood cell count $24100 / \mathrm{mm}^{3}$ (normal range $4500-10500 \mathrm{~mm}^{3}$ ), erythrocyte sedimentation rate $52 \mathrm{~mm} / \mathrm{hr}$ (normal range $0-10 \mathrm{~mm} / \mathrm{hr}$ ), C-reactive protein $1.67 \mu \mathrm{g} / 1$ (normal range $0-0.5 \mu \mathrm{g} / \mathrm{l}$ ), blood glucose $287 \mathrm{mg} / \mathrm{dl}$ (normal range 70-110 mg/dl) and 4+ glucose and $3+$ ketones in the urine. Diabetic ketosis was diagnosed and treatment initiated. Cranial x-ray showed a slightly brush like appearance on the outer table of the vertical skull. Magnetic resonance imaging (MRI) revealed a subcutaneous soft tissue swelling and subperiosteal abscess in the vertex region associated with dural thickening and perisinusal irregularities of epidural space (Fig.1).

Operative findings: A bicoronal skin incision was performed under local anesthesia. After the incision of galea, purulent material oozed out, the subperiosteal abscess was drained and samples were taken for culture and gram staining. Granular tissue underlying the abscess pouch was removed. There was minimal erosion of the bone surface around the sagittal suture and this area was curetted. The remaining bone was intact so further bone removal was thought to be unnecessary. The wound was irrigated with antibiotic solution and scalp was closed in layers, leaving a drain inserted under it.

Postoperatively, the patient had an uneventful recovery and remained neurologically intact. We did not encounter any problem in wound healing. His blood glucose level was maintained within normal limits using fractionized crystallized insulin therapy. Histopathological examination of the granulation tissue under the abscess pouch revealed an abscess wall with chronic inflammatory cells. Staphylococcus aureus was found in the cultures. The patient received parenteral ampicilline+sulbactam for 6 weeks followed by oral amoxicillin+klavulinik acid $625 \mathrm{mg}$ tid therapy for another 6 weeks. His postoperative course was uneventful. Control MRI obtained nine months later revealed complete resolution of the abscess (Fig. 2) . 


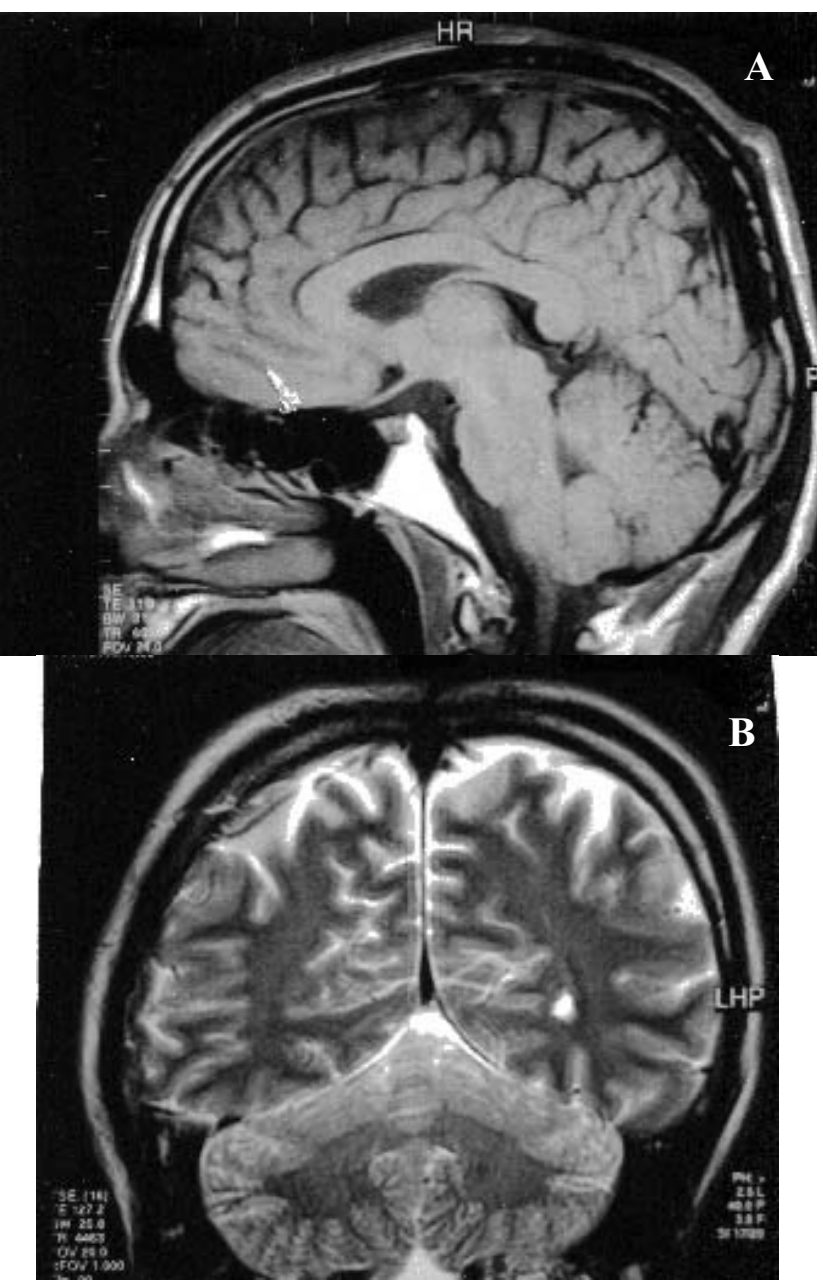

Figure 2: Sagittal T1-weighted (A) and coronal T2 weighted (B) magnetic resonance images obtained 9 months after operation demonstrating complete resolution of the abscess.

\section{Discussion}

Subperiosteal abscess and osteomyelitis involving the outer table of the cranium are the main features of PPT. Occasionally the infection spreads intracranially. Involvement of the inner table may lead to extradural granulation tissue formation or epidural abscess. The dura forms an effective barrier against the spread of infection. However, risk of septic thrombophlebitis in the sagittal sinus, subdural empyema and brain abscess still exists due to haematogenous invasion via valveless diploic veins ${ }^{6}$. Neuroimaging is mandatory to allow exclusion of intracranial complications. Although Computerized tomography (CT) scan is accepted as the most adequate study to investigate osteomyelitis, MRI supplies valuable information about extent of disease and involvement of intracranial structures $^{1}$.
$2005 ; 16: 54-57$

This patient had sustained a trauma 14 years ago and no other cause could be determined to explain the infection localized under the old traumatic scalp scar. In diabetic patients, local infection or abscess occurrence can be seen even decades after trauma ${ }^{7}$. The complications associated with diabetes such as macroangiopathy, microangiopathy, ketoacidosis, and hyperglycemia result in immunosuppression, susceptibility to bacterial infection and impaired wound healing. Diabetic microangiopathy contributes to compromised delivery of nutrients to surrounding tissues and poor elimination of metabolic waste products. immunosuppression includes impaired neutrophil chemotaxis, phagocytosis and adhesion ${ }^{8}$. Dehydration and electrolyte disturbances, increase susceptibility to infection. Therefore we may assume that due to the type 1 diabetes mellitus of our patient, immune functions were impaired and contributed to the activation of pathogenic bacteria, resulting in localized infection over the posttraumatic tissue of scalp. On the other hand, infection deteriorates the metabolic situation in diabetes, necessitating higher insulin doses.

Surgical intervention is the treatment of choice in PPT. A thorough debridement of granulation and drainage of pus are mandatory ${ }^{3}$. Various reports emphasize importance of removal of the infected bone and underlying epidural granulation tissue without breaching the dura ${ }^{2,4}$. However we did not perform a craniotomy as the bone was visually intact, without any lysis, sclerosis or pus. Instead we scrapped off the outer layer of the bone using a curette. As MR imaging with gadolinium enhancement revealed the extent of dural inflammation to be very limited in size but located over the sagittal sinus, we considered that it would be both unnecessary and dangerous to make a craniotomy. We treated our patient with a simple surgical abscess drainage followed by prolonged use of antibiotics and achieved complete therapy. Control of diabetes by maintenance of the blood glucose levels within normal levels was also an important factor in avoiding any complication or aggravation of the infection.

\section{References}

1. Babu, R.P., Todor, R., Kasoff, S.S.: Pott's puffy tumor: the forgotten entity. Case report. J Neurosurg 1996; 84: 110112

2. Bagdatoglu, C., Guleryuz, A., Ersoz, G., Talas, D.U., Kandemir, O., Koksel, T.: A rare clinical entity: Pott's puffy tumor. A case report. Pediatr Neurosurg 2001; 34: 156-158

3. Bambakidis, N.C., Cohen, A.R.: Intracranial complications of frontal sinusitis in children: Pott's puffy tumor revisited. Pediatr Neurosurg 2001; 35: 82-89

4. Clark, J.R., Lim, J.K., Poole, M.: Pott's puffy tumour: a clinical variant. Aust N Z J Surg 1999; 69: 759-762 
5. Flamm, E.S.: Percivall Pott: an 18th century neurosurgeon. J Neurosurg 1992; 76: 319-326

6. Guillén, A., Brell, M., Cardona, E., Claramunt, E., Costa, J.M.: Pott's puffy tumour: still not an eradicated entity. Childs Nerv Syst 2001; 17: 359-362

7. Marquardt, G., Schick, U., Moller-Hartmann, W.: Brain abscess decades after a penetrating shrapnel injury. Br J Neurosurg 2000; 14: 246-248

8. Perchel, W.T., Langefeld, T.W., Federlin, K.: Susceptibility to infections in diabetes-effects on metabolism. Immun
Infekt 1995; 23: 196-200

9. Tattersall, R.: Pott's puffy tumour. Lancet 2002; 359: 1060-1063

Evliyaoğlu, Ç.;. Bademci, G.; Yucel, E.; Keskil, S.: Pott's puffy tumor of the vertex years after trauma in a diabetic patient: case report. Neurocirugía 2005; 16: 54-57.

Correspondencia postal: Çetin Evliyaoğlu, M.D. Yılmaz Çolpan Sok. 7/3. Oran Sitesi, Oran, 06450 Ankara, Turkey. 